\title{
DEPLETION OF ENDOGENOUS ZINC STORES INDUCES OXIDATIVE STRESS AND CELL DEATH IN HUMAN MELANOMA CELLS
}

\author{
Emil Rudolf, Miroslav Červinka
}

\author{
Charles University in Prague, Faculty of Medicine in Hradec Králové, Czech Republic: Department of Medical Biology \\ and Genetics
}

\begin{abstract}
Summary: The role of intracellular free zinc and its chelation by TPEN ( $N, N, N^{\prime}, N^{\prime}$ - tetrakis(2-pyridylmethyl)ethylenediamine) was studied in Bowes human melanoma cells. The content of free $\mathrm{Zn}$ pools was determined by fluorescent probe Zinquin. Depletion of zinc triggered apoptosis confirmed by cell blebbing, changes in mitochondrial transmembrane potential and GSH levels, caspase-3 activation and nuclear fragmentation. Apoptosis was only partially prevented by cyclosporin A or N-acetylcystein, suggesting various independent but likely interrelated mechanisms participating in this process.
\end{abstract}

Key words: Human melanoma cells; Labile zinc; Cell death; Mitochondria; Oxidative stress

\section{Introduction}

Zinc $(\mathrm{Zn})$ is an essential component of all eukaryotic cells, where it is required for many biological activities including growth regulatory processes (10). In the cell, $\mathrm{Zn}$ ions may exist in a form of permanently bound protein complexes (metalloenzymes or $\mathrm{Zn}$ fingers) or be relatively free, constituting loosely bound labile $\mathrm{Zn}$ stores, which are participating in intracellular Zn fluxes. Under physiological conditions, cellular $\mathrm{Zn}$ content is strictly regulated, however, the presence of higher $\mathrm{Zn}$ concentrations in the surrounding environment results in an overall increase of intracellular $\mathrm{Zn}$ levels and is associated with documented Zn toxicity $(4,17)$. Conversely, many studies have shown that $\mathrm{Zn}$ deficiency may lead to rapid depletion of endogenous $\mathrm{Zn}$ pools, thereby inducing oxidative stress and apoptosis in the exposed cells $(5,11,15,23)$.

It is nowadays understood that the impaired regulation of normal cell death signaling most probably underlies cell malignant transformation. Furthermore, recent observations suggest that this process might occur or be enhanced in the presence of $\mathrm{Zn}$ ions since they are able to suppress apoptosis by interfering with several molecular targets in numerous cell types $(4,14,22)$.

Thus the purpose of this work was to study the biological effects and significance of deprivation of labile endogenous $\mathrm{Zn}$ stores in human melanoma cells, which are known to be resistant to spontaneous or induced cell death $(16,20)$. We report here that the depletion of intracellular $\mathrm{Zn}$ stores by permeable $\mathrm{Zn}$ chelator $N, N, N$, $N$ 'tetrakis (2-pyridylmethyl) ethylenediamine (TPEN) induces morpho- logical changes and decreases mitochondrial activity of Bowes melanoma cells while generating oxidative stress and cell death - apoptosis.

\section{Materials and Methods}

\section{Chemicals}

Zinc sulfate; $N, N, N^{\prime}, N$ '- tetrakis(2-pyridylmethyl)ethylenediamine (TPEN); N-acetylcystein (NAC); Zinquin $\mathrm{E}$ (ethyl ester), glutathione reductase (GR); $\beta$-NADPH; reduced glutathione (GSH); oxidized glutathione (GSSH), 5,5'-dithio-bis(2-nitrobenzoic acid) (DTNB);

4', 6-diamidino-2-phenylindole (DAPI); Triton-X and cyclosporin A were purchased from Sigma-Aldrich (Prague, Czech Republic).

4-[3-(4-Iodophenyl)-2-(4-nitrophenyl)-2H-5-tetrazolio]-1,3-benzene disulphonate (WST-1) was from Boehringer Mannheim-Roche (Basel, Switzerland). JC-9 dye and secondary antibodies for caspase- 3 detection were from Molecular Probes, Inc. (Eugene, U.S.A.) and from EXBIO (EXBIO-Institute of Molecular Genetics, Prague, Czech Republic). Monospecific antiserum for the detection of activated caspase-3 was obtained from New England Biolabs, Inc. (New England Biolabs, Beverly, U.S.A.). All other chemicals were of highest analytical grade.

\section{Cell line}

Bowes human melanoma cell line (ATCC, No. CRL 9607, Manassas, United States) was grown as adherent cell culture in DMEM PAN (Aidenbach, Germany) supplemented with $10 \%$ fetal bovine serum (Aidenbach, Ger- 
many), $100 \mathrm{U} / \mathrm{ml}$ penicillin, and $100 \mathrm{~g} / \mathrm{ml}$ streptomycin. Cells were maintained in an incubator at $37{ }^{\circ} \mathrm{C}$ and $5 \%$ $\mathrm{CO}_{2}$ atmosphere and were passaged two times a week using $0.05 \%$ trypsin/EDTA. Only mycoplasma-free cells were used for experiments.

\section{Measurement of intracellular labile $Z \mathbf{n}$}

Cultures pretreated with $25-100 \mu \mathrm{M}$ TPEN $\left(2 \mathrm{~h}, 37^{\circ} \mathrm{C}\right)$ were washed with phosphate buffered saline (PBS) and incubated with $25 \mu \mathrm{M}$ Zinquin E in DMEM for $30 \mathrm{~min}$ at $37^{\circ} \mathrm{C}$. After $30 \mathrm{~min}$, the slides were washed with PBS and Zinquin fluorescence was recorded under a fluorescence microscope Nikon Eclipse E400 (Nikon Corporation, Kanagawa, Japan) using an excitation filter 330-380 nm and emission filter $420 \mathrm{~nm}$. The images were collected with a digital color matrix camera COOL 1300 (VDS, Vosskühler, Germany) and LUCIA DI Image Analysis System (Laboratory Imaging Ltd., Prague, Czech Republic). In all experiments, the results were compared with those originating from untreated cultures.

\section{Bowes human melanoma cell toxicity}

Effects of labile $\mathrm{Zn}$ deprivation on human melanoma cells were assessed by morphological analysis as well as by measurement of mitochondrial activity. Cultures were exposed to $25-100 \mu \mathrm{M}$ TPEN $\left(2 \mathrm{~h}, 37^{\circ} \mathrm{C}\right)$, rinsed with phosphate buffered saline (PBS) and resuspended in DMEM PAN without serum. Their morphological appearance was photographed at regular intervals under an inverted microscope Olympus IX-70 (Olympus Optical Co, Ltd., Tokyo, Japan) by a digital camera Olympus C-4040 (Olympus Optical CO, Ltd., Tokyo, Japan). Mitochondrial activity was quantified by WST-1 colorimetric assay, which is based on the cleavage of the tetrazolium salt to colored formazan by mitochondrial dehydrogenases in viable cells. Melanoma cells $(6,000$ cells/well) in $200 \mu \mathrm{l}$ of DMEM PAN with $10 \%$ fetal bovine serum were seeded into 96-well microtiter plates, with the first two columns of wells without cells (blank) and left overnight at $37{ }^{\circ} \mathrm{C}$ and in $5 \% \mathrm{CO}_{2}$. Next, the cells were treated with varying concentrations of TPEN for up to $2 \mathrm{~h}$. After $2 \mathrm{~h}$, the cells were rinsed with PBS and $100 \mu \mathrm{l}$ of WST-1 was added. The cells were further incubated for $2 \mathrm{~h}$ upon same conditions. The absorbance of samples was recorded at $450 \mathrm{~nm}$ with $650 \mathrm{~nm}$ of reference wavelength by a scanning multiwell spectrophotometer Titertek Multiscan MCC/340 (ICN Biochemicals, Frankfurt, Germany). In all cases, the absorbance of TPEN in medium alone was recorded to determine whether it interfered with the assay.

\section{GSH assay}

Control and treated cells were detached by a cell scraper and collected by centrifugation at $1,000 \times \mathrm{g}$ for $5 \mathrm{~min}$ at $4{ }^{\circ} \mathrm{C}$ (JOUAN, Nantes, France). The obtained pellet was rinsed with PBS and mixed with distilled water to the final volume of $2 \mathrm{ml}$. Aliquots of this lyzate were either used for measurement of protein content by bicinchoninic acid assay - BCA assay (Bicinchoninic acid kit for protein determination, Sigma-Aldrich, Prague, Czech Republic) or diluted with EDTA-phosphate buffer and used for GSH assay. For this assay, sample aliquots were mixed with NADPH, GR and DTNB. After adding NADPH, the change in absorbance during 6 min was followed at $412 \mathrm{~nm}$ using a Shimadzu UV - Visible Spectrophotometer UV - 1601 (SHIMADZU DEUTSCHLAND GmbH, Duisburg, Germany). Data were expressed as $\mathrm{nM} \mathrm{GSH} / \mathrm{mg}$ protein on the basis of a GSH calibration curve.

\section{Mitochondrial transmembrane potential $(\Delta \Phi m)$ analysis}

Bowes melanoma cells were seeded into cultivation flasks and allowed to grow overnight. After treatment with TPEN, cells were rinsed in PBS and stained with JC-9 dye for $15 \mathrm{~min}$ at $37^{\circ} \mathrm{C}$. Mitochondrial membrane potential was assessed by flow cytometry analysis using a flow cytometer equipped with cell sorter (COULTER EPICS Elite ESP, Coulter, U.S.A.). Mitochondrial transmembrane potential changes were indicated as an increase in fluorescence intensity at $528 \mathrm{~nm}$.

\section{Detection of apoptosis}

The slides with TPEN-treated and control cells were fixed with $4 \%$ formaldehyde solution. The specimens were rinsed with phosphate saline buffer with Triton X (PBS-T) and a primary antibody against caspase- 3 was added. After overnight cultivation a secondary antibody (anti-mouse conjugated with Alexa 488) was added, and the cells were incubated for $90 \mathrm{~min}$ at RT. The specimens were post-labeled with DAPI, mounted into SlowFade ${ }^{\circledR}$ medium (Molecular Probes, Inc. Eugene, U.S.A.) and examined under a fluorescence microscope Nikon Eclipse E400 (Nikon Corporation, Kanagawa) equipped with a digital color matrix camera COOL 1300 (VDS, Vosskühler, Germany), using an excitation filter $510-560 \mathrm{~nm}$ and emission filter $590 \mathrm{~nm}$. Photographs were taken using the software LUCIA DI Image Analysis System LIM (Laboratory Imaging Ltd., Prague, Czech Republic) and analyzed. All the experiments were done in triplicate.

\section{Statistics}

Statistical analysis was carried out with a statistical program GraphPad Prism (GraphPad Software, Inc. San Diego, U.S.A.). We used one-way Anova test with Dunnet's post test for multiple comparisons. Results were compared with control samples, and means were considered significant if $\mathrm{P}<0.01$.

\section{Results}

Intracellular labile Zn fluorescence. Endogenous labile $\mathrm{Zn}$ stores appear to localize mostly in the cytoplasm of Bowes human melanoma cells (Fig. 1A). Membrane per- 


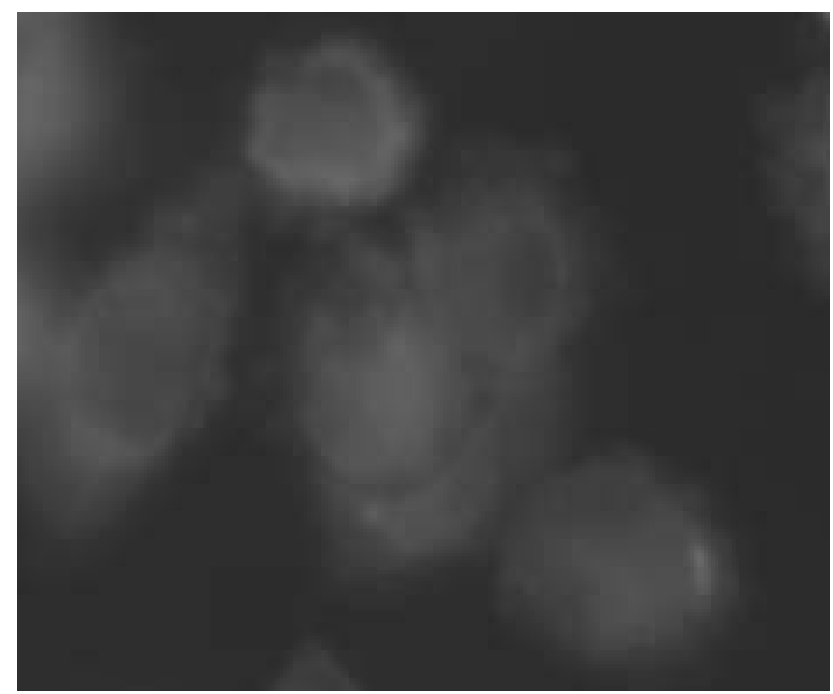

Fig. 1A: Intracellular labile zinc stores in Bowes human melanoma cells after incubation with $25 \mu \mathrm{M}$ Zinquin. Zinc localizes predominantly to the cytoplasm of cells. Fluorescence $600 \mathrm{x}$.

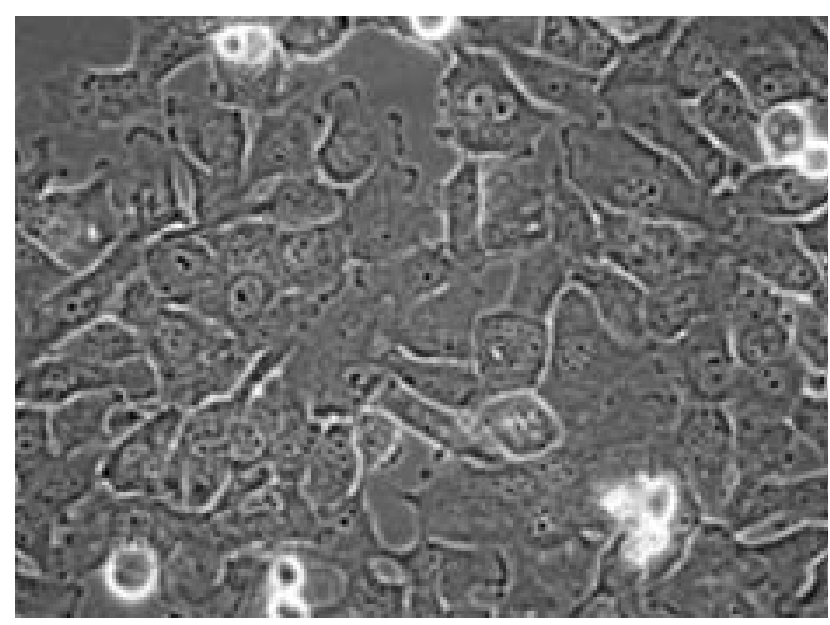

Fig. 2A: Bowes human melanoma cells in control cultures. Phase contrast $400 x$.

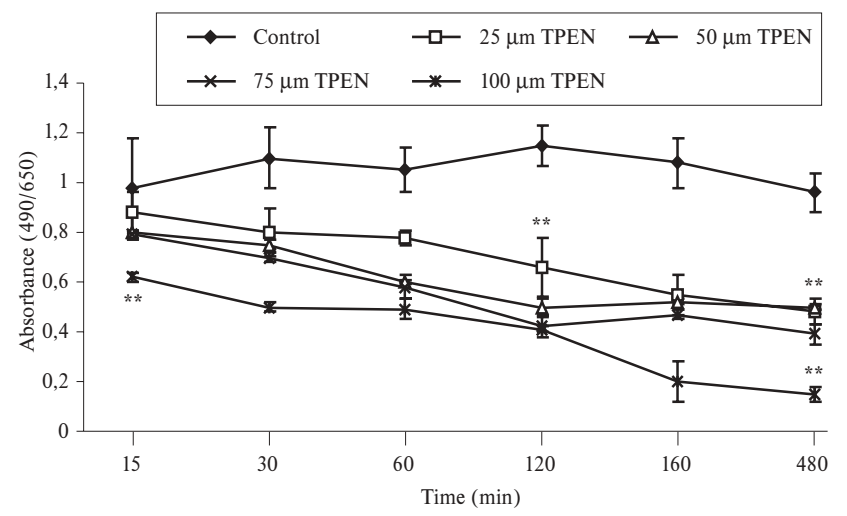

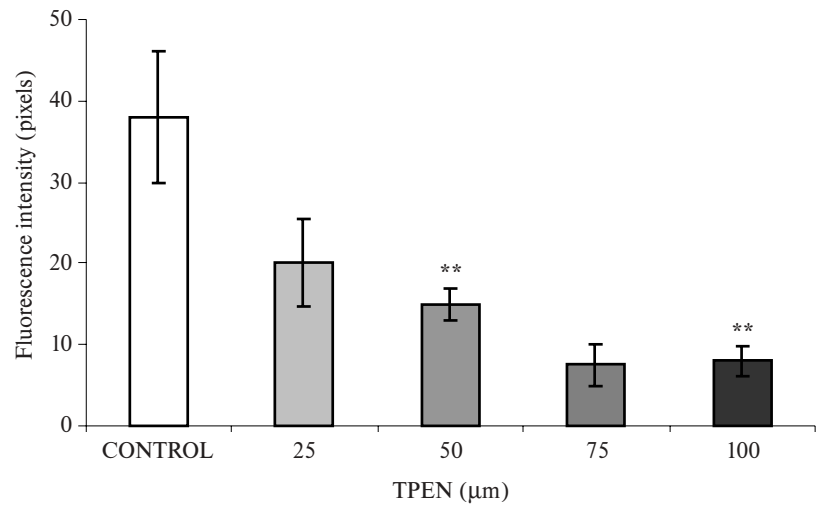

Fig. 1B: Time and concentration dependent reduction of intensity of Zinquin fluorescence after exposure to various of TPEN concentrations. Cultures of Bowes human melanoma cells were exposed for $2 \mathrm{~h}$ to this membrane permeable zinc chelator and changes in intracellular zinc content were measured using an image analysis system. Values represent the mean $\pm \mathrm{SD}$ of three different experiments. $* * \mathrm{P}<0.01$ with one way-Anova test and Dunnet's post test for multiple comparisons.

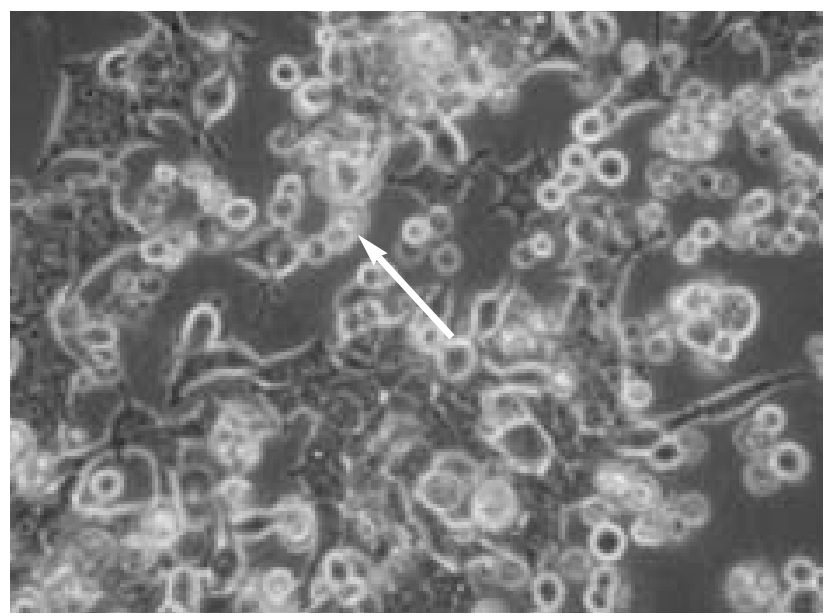

Fig. 2B: Bowes human melanoma cells treated with membrane permeable chelator of zinc TPEN. Following $2 \mathrm{~h}$ exposure, many cells lost adherence and became rounded. Phase contrast 400x.

Fig. 2C: The activity of mitochondrial enzymes as measured by WST-1 tetrazolium cleavage assay in Bowes human melanoma cells after treatment with various concentrations of membrane permeable zinc chelator TPEN. All the employed TPEN concentrations suppressed mitochondrial enzymes, in case of the highest TPEN concentration as early as $15 \mathrm{~min}$ after the beginning of treatment. Values represent the mean \pm SD of three independent experiments. $* * \mathrm{P}<0.01$ significantly different from control with one wayAnova test and Dunnet's post test for multiple comparisons. 
meable $\mathrm{Zn}$ chelator TPEN was capable of reducing labile $\mathrm{Zn}$ content in the same cells in a concentration-dependent manner (Fig. 1B).

Effect of $\mathrm{Zn}$ deprivation on Bowes cell morphology and mitochondrial enzymes. Exposure to $<25 \mu \mathrm{M}$ TPEN had no effect on appearance of studied cells as well as on performance of mitochondrial enzymes during $8 \mathrm{~h}$ (data not shown). TPEN at concentrations of 25-100 $\mu \mathrm{M}$ caused vacuolization and subsequent cell rounding followed in some cases by moderate blebbing (Fig. 2A,B). Concurrently, activity of mitochondrial enzymes was suppressed. These

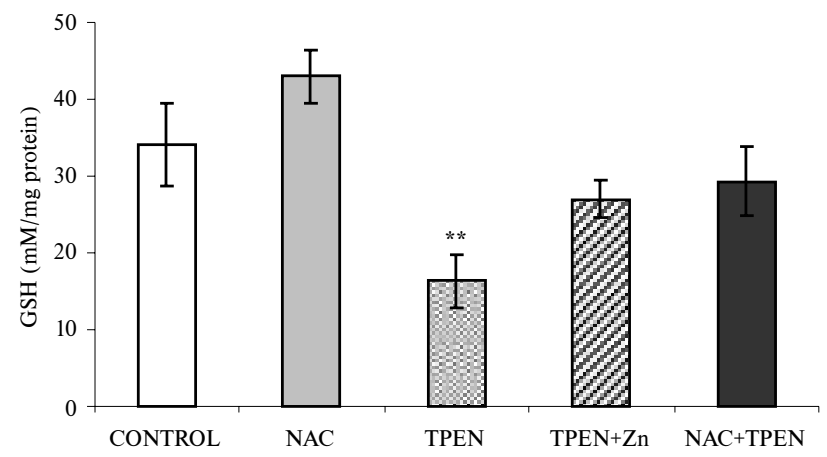

Fig. 3: The levels of reduced glutahione (GSH) in Bowes human melanoma cells. Zinc chelation induced reduction in GSH content, which was partially preventable by addition of zinc or pretreatment of cells with NAC. Values represent the mean $\pm \mathrm{SD}$ of three independent experiments. $* * \mathrm{P}<0.01$ significantly different from control with one wayAnova test and Dunnet's post test for multiple comparisons.

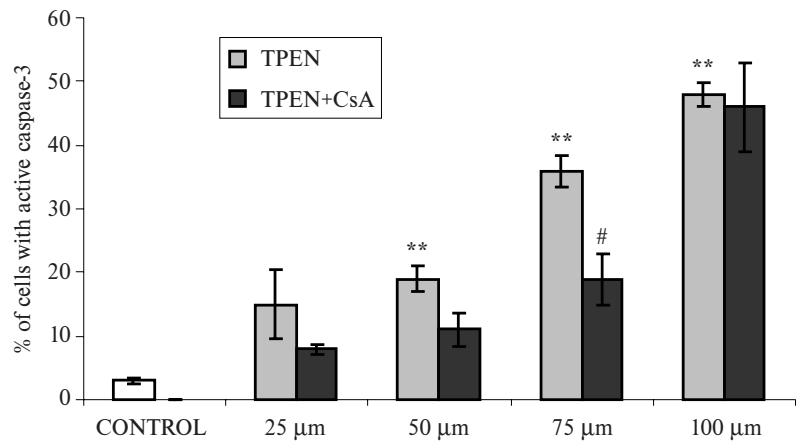

Fig. 4B: Apoptosis in Bowes human melanoma cells treated with various TPEN concentrations with or without 5 $\mu \mathrm{M}$ cyclosporin $\mathrm{A}$. In all cases, zinc chelation resulted in activation of caspase-3, which was partially reduced by cyclosporin A. Values represent the mean \pm SD of three independent experiments. ${ }^{* *} \mathrm{P}<0.01$ significantly different from control, \# significantly different from TPEN treated cultures with one way-Anova test and Dunnet's post test for multiple comparisons. changes were more pronounced and occurred earlier with increasing concentrations of employed TPEN (Fig. 2C), with the highest concentration producing the first changes as early as 15 min after the beginning of the treatment.

Effect of $\mathrm{Zn}$ deficiency on oxidative stress. Various thiols are known to participate in intracellular redox balance mechanisms that protect against oxidative stress responsible for cell injury and cell death. In order to verify the relationship between $\mathrm{Zn}$ status, oxidative stress and spontaneous cell death, the effect of endogenous labile $\mathrm{Zn}$ deficiency on intracellular GSH was examined. TPEN-in-

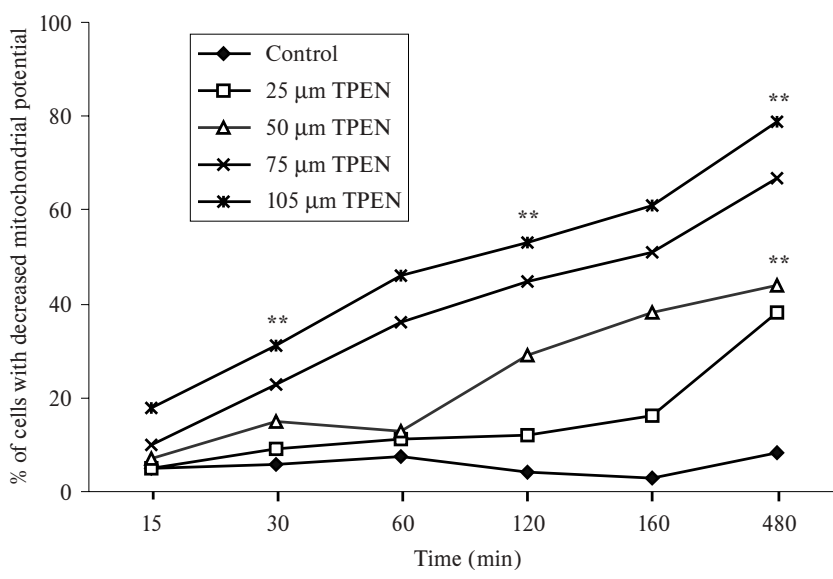

Fig. 4A: Mitochondrial membrane potential in Bowes human melanoma cells treated with various TPEN concentrations. In all cases, zinc chelation promoted a decrease in mitochondrial potential - an early sign of apoptosis. Values represent the mean \pm SD of three independent experiments. $* * \mathrm{P}<0.01$ significantly different from control with one wayAnova test and Dunnet's post test for multiple comparisons.

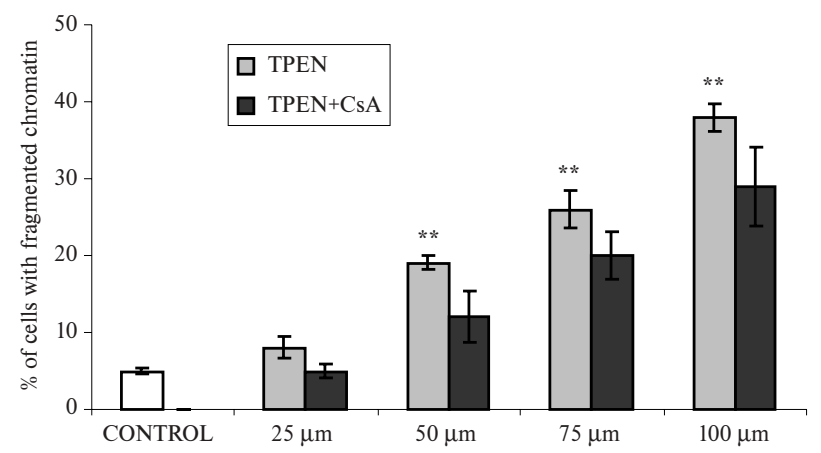

Fig. 4C: Apoptosis in Bowes human melanoma cells treated with various TPEN concentrations with or without 5 $\mu \mathrm{M}$ cyclosporin $\mathrm{A}$. In all cases, zinc chelation resulted in nuclear fragmentation, which was not significantly reduced by cyclosporin $A$. Values represent the mean \pm SD of three independent experiments. ${ }^{*} \mathrm{P}<0.01$ significantly different from control with one way-Anova test and Dunnet's post test for multiple comparisons 
duced labile $\mathrm{Zn}$ depletion caused a decrease in intracellular GSH which was partially prevented by addition of $\mathrm{ZnSO}_{4}$ or pretreatment with NAC (Fig. 3).

Role of mitochondria in $\mathrm{Zn}$ depletion-induced apoptosis. Incubation of Bowes human melanoma cells with $<25 \mu \mathrm{M}$ TPEN had a very little effect on mitochondrial membrane potential and other observed markers of apoptosis; i.e. activation of caspase-3 and nuclear fragmentation (data not shown). When higher TPEN concentrations were added to cultures, mitochondrial membrane potential decreased in a time and concentration dependent manner, suggesting an impaired functioning of mitochondrial respiratory chain (Fig. 4A). In addition, mitochondrial alteration was paralleled by caspase-3 activation and nuclear fragmentation hallmarks of apoptotic cascade. To determine whether caspase- 3 activation was mediated by cytochrome c released from mitochondria, cultures were pretreated or co-treated with $5 \mu \mathrm{M}$ cyclosporin A which is known as a suppressor of cytochrome $\mathrm{c}$ release. In all but the highest TPEN concentration $(100 \mu \mathrm{M})$, caspase-3 activation and nuclear fragmentation were reduced or at least delayed in time (Fig. 4B,C).

\section{Discussion}

Malignant melanoma belongs among the most aggressive forms of skin cancer, which is often resistant to chemotherapeutically induced cell death. Although it has been shown that melanoma cells are capable of undergoing apoptosis via several distinct mechanisms, there is also compelling evidence suggesting that the same cells may employ a variety of mechanisms for regulating apoptosis and generating apoptosis deficiency. Thus one of the aims of current research concerning malignant melanoma is to elucidate how melanoma cells circumvent proapoptotic signals, and which apoptotic pathways are possibly altered in them $(6,18,20)$.

It is nowadays known that $\mathrm{Zn}$ is a critical element in management of many cellular processes. Recent studies have shown that besides its physiological role, $\mathrm{Zn}$ appears to be involved in regulation of cell proliferation and cell death apoptosis or necrosis. In the past decade, research into $\mathrm{Zn}$ status and mechanisms of cell death has helped identify the endogenous labile $\mathrm{Zn}$ pools whose altered homeostasis have been reported to accompany numerous pathological states including cancer $(1,5)$.

In our work we have focused on the role of labile $\mathrm{Zn}$ pools in regulation of apoptosis in Bowes human melanoma cells. Incubation of Bowes cells with a specific fluorophore Zinquin showed that these cells, indeed, contain labile $\mathrm{Zn}$ ions distributed in the cytoplasm (Fig. 1A). The fact that these endogenous $\mathrm{Zn}$ stores may be reduced or depleted by addition of a membrane permeable $\mathrm{Zn}$ chelator TPEN concurs with observations made on different cellular and tissue models $(21,22,23)$.

In order to confirm the nature of changes promoted by TPEN in Bowes human melanoma cells, we followed seve- ral apoptosis-specific markers. Chelation of endogenous labile $\mathrm{Zn}$ brought a loss of cellular adherence, cell rounding and shrinkage, which was followed by moderate and rather random membrane blebbing (Fig. 2B). It has been noted that morphological features of apoptosis are preceded by other, more discreet changes such as a shift in redox balance. Since $\mathrm{Zn}$ is known as an antioxidant factor, being most active in maintenance of CuZn-SOD stability as well as in protection of thiol groups (8), we examined the effects of labile $\mathrm{Zn}$ deprivation on cellular GSH levels and subsequent apoptosis. We found that upon TPEN treatment, GSH concentration in Bowes cells decreased and this reduction was partially abolished by concurrent addition of NAC, a precursor in GSH synthesis, or external Zn. Still, apoptosis induced by $\mathrm{Zn}$ depletion was not suppressed entirely by either of the above-mentioned chemicals (i.e. $\mathrm{Zn}$ or NAC). This finding is in contrast with the results of the study conducted on rat hepatocytes where TPEN induced apoptosis was blocked by NAC (13). One possible explanation of this discrepancy might reside in the type of the employed model. Unlike hepatocytes, which are metabolically very active and harbor high concentrations of GSH, mesenchymal cells from which melanoma arises show lower activity and, perhaps, a varying sensitivity to redox changes. Furthermore, as stated before melanoma cells may possess unpredictably altered signaling pathways and thus it is possible that $\mathrm{Zn}$ depletion started other mechanisms, GSH independent, which eventually triggered an executory apoptosis cascade.

Mitochondria represent the cellular compartment responsible for generation of energy in the form of ATP. In addition, they may activate apoptosis by releasing cytochrome c along with other proapoptotic proteins, thereby activating caspase-9 and caspase-3, the major apoptosis execution enzymes (12). Release of mitochondrial cytochrome c have been reported to occur via permeability transition pore (PTP) whose opening is triggered by various signals such as a mechanical insult to the mitochondrial membrane, decreased expression of antiapoptotic proteins or suppression of mitochondrial function $(7,9,12)$. In addition, recent studies indicate that mobilization of endogenous labile $\mathrm{Zn}$ pools might interfere with normal functioning of mitochondria too and be responsible for activation of apoptosis (19). Consistent with these reports we found that chelation of intracellular labile $\mathrm{Zn}$ pools corresponds well with a detected impaired function of mitochondrial dehydrogenases as well as with loss of mitochondrial transmembrane potential. The later parameter, in particular, is known to be an early feature of apoptosis and provides indirect evidence on possible activation of PTP. To determine whether labile $\mathrm{Zn}$ depletion induced release of cytochrome c from mitochondria in Bowes human melanoma cells, we pretreated or co-treated cultures with PTP-blocking agent cyclosporin A. We found that in all cultures treated with various concentrations of TPEN cyclosporin A was able to decrease basic markers of apoptosis - nuclear fragmentation and 
activation of caspase- 3 although this decrease was found significant only at $75 \mu \mathrm{M}$ TPEN. This observation clearly suggests that some intracellular $\mathrm{Zn}$ localizes to mitochondria and its sequestration from this compartment likely induces various changes in mitochondria culminating in release of apoptosis-activating proteins. The fact that apoptosis was not entirely prevented by cyclosporin A implies that depletion of endogenous $\mathrm{Zn}$ interferes with other apoptosis-relevant targets.

One of them is most possibly procaspase- 3 , whose conversion to the active form - caspase- 3 has been shown to be inhibited in the presence of $\mathrm{Zn}$ ions $(2,3)$. Our data prove that $\mathrm{Zn}$-deprived Bowes cells are caspase- 3 positive in comparison with control cells. Addition of external $\mathrm{Zn}$ to such cells then suppressed a number of caspase- 3 positive cells or at least delayed this process (data not shown).

\section{Conclusion}

Bowes human melanoma cells contain labile $\mathrm{Zn}$ stores which localize mostly to the cytoplasm and possibly to mitochondria too. TPEN induced $\mathrm{Zn}$ deprivation leads to a concentration and time dependent activation of apoptosis by at least three interrelated mechanisms; i.e. suppression of mitochondrial function and release of cytochrome c, triggering redox changes exemplified by reduction of $\mathrm{GSH}$, and direct activation of caspase-3. Temporal and spatial organization of these mechanisms as well as determination of the exact relationship between endogenous $\mathrm{Zn}$ pools and mitochondria in the process of apoptosis remain obscure, thus calling for further studies.

\section{Acknowledgment}

This work was supported by Ministry of Education Czech Republic Research Project MSM 111500001 Serious organ failure, experimental and clinical aspects, possibilities for prevention and therapeutic management.

\section{References}

1. Carter JE, Truong-Tran AQ, Grosser D, Ho L, Ruffin RE, Zalewski PD. Involvement of redox events in caspase activation in zinc-depleted airway epithelial cells. Biochem Biophys Res Commun 2002:297:1062-70.

2. Chai F, Truong-Tran AQ, Evdokiou A, Young GP, Zalewski PD. Intracellular zinc depletion induces caspase activation and $\mathrm{p} 21 \mathrm{Waf} 1 / \mathrm{Cip} 1$ cleavage in human epithelial cell lines. J Infect Dis. 2000;182(Suppl 1):S85-S92.

3. Chimienti F, Seve M, Richard S, Mathieu J, Favier A. Role of cellular zinc in programmed cell death: temporal relationship between zinc depletion, activation of caspases, and cleavage of $\mathrm{Sp}$ family transcription factors. Biochem Pharmacol 2001;62:51-62
4. Fukamachi Y, Karasaki Y, Sugiura T et al. Zinc suppresses apoptosis of U937 cells induced by hydrogen peroxide through an increase in bcl-2/bax ratio. Biochem Biophys Res Commun 1998;246:364-9.

5. Ho E, Courtemanche C, Ames BN. Zinc deficiency induces oxidative DNA damage and increases p53 expression in human lung fibroblasts. J Nutr 2003;133:2543-48.

6. Hussein MR, Haemel AK, Wood GS. Apoptosis and melanoma: molecular mechanisms. J Pathol 2003;199:275-88.

7. Jiang D, Sullivan PD, Sensi SL, Steward O, Weiss JH. Zn(2+) induces permeability transition pore opening and release of pro-apoptotic peptides from neuronal mitochondria. J Biol Chem 2001;276:47524-29.

8. Kojima-Yuasa A, Ohkita T, Yukami K et al. Involvement of intracellular glutathione in zinc deficiency-induced activation of hepatic stellate cells. Chem Biol Interact 2003;146:89-99.

9. Kroemer G. Mitochondrial control of apoptosis: an introduction. Biochem Biophys Res Commun 2003;304:433-35.

10. MacDonald RS. The role of zinc in growth and cell proliferation. J Nutr 2000; 130:1500S-8S.

11. McCabe Jr MJ, Jiang SA, Orrenium S. Chelation of intracellular zinc triggers apoptosis in mature thymocytes. Lab Invest 1993;69:101-10.

12. Mignotte B, Vayssiere JL. Mitochondria and apoptosis. Eur J Biochem 1998;252:1-15

13. Nakatani T, Taearamoto M, Kennedy DO, Kojima A, Matsui-Yuasa. Apoptosis induced by chelation of intracellular zinc is associated with depletion of cellular reduced glutathione level in rat hepatocytes. Chem Biol Interact 2000;125 $151-63$.

14. Perry DK, Smyth MJ, Stennicke HR et al. Zinc is a potent inhibitor of the apoptotic protease, caspase-3. A novel target for zinc in the inhibition of apoptosis. J Biol Chem 1997;272:18530-33.

15. Reaves SK, Fanzo JC, Arima K, Wu JY, Wang YR, Lei KY. Expression of the p53 tumor suppressor gene is up-regulated by depletion of intracellular zinc in $\mathrm{HepG} 2$ cells. J Nutr 2000;130:1688-94

16. Rockmann H, Schadendorf D. Drug resistance in human melanoma: mechanisms and therapeutic opportunities. Onkologie 2003;26:581-7.

17. Rudolf E, Rudolf K, Radocha J, Peychl J, Cervinka M. The role of zinc in modulation of life and death of Hep-2 cells. Biometals 2003;16:295-309.

18. Sander CS, Hamm F, Elsner P, Thiele JJ. Oxidative stress in malignant melanoma and non-melanoma skin cancer. Br J Dermatol 2003;148:913-22.

19. Sensi SL, Ton-That D, Sullivan PG et al. Modulation of mitochondrial function by endogenous $\mathrm{Zn}^{2+}$ pools. Proc Natl Acad Sci U.S.A. 2003;100:6157-62.

20. Soengas MS, Lowe SW. Apoptosis and melanoma chemoresistance. Oncogene 2003;22:3138-51.

21. Tang ZL, Wasserloos K, St Croix CM, Pitt BR. Role of zinc in pulmonary endothelial cell response to oxidative stress. Am J Physiol Lung Cell Mol Physiol 2001;281:L243-L249.

22. Truong-Tran AQ, Ho LH, Chai F, Zalewski PD. Cellular zinc fluxes and the regulation of apoptosis/gene-directed cell death. J Nutr 2000;130:1459S-1466S.

23. Wang X, Fosmire GJ, Gay CV, Leach RMJ. Short-term zinc deficiency inhibits chondrocyte proliferation and induces cell apoptosis in the epiphyseal growth plate of young chickens. J Nutr 2002;132:665-73.

Submitted January 2004. Accepted April 2004.

PharmDr. Emil Rudolf, Ph.D., Charles University in Prague, Faculty of Medicine in Hradec Králové, Department of Medical Biology and Genetics, Šimkova 870, 50038 Hradec Králové, Czech Republic. e-mail: rudolf@lfhk.cuni.cz 